\title{
Journal of Research in Engineering and Applied Sciences
}

\section{SHORT PAPER: GENERATION OF ELECTRICITY USING SOLAR WINDOW BLINDS}

\author{
Akshata Gaurkgede ${ }^{1}$, Gauri Rane ${ }^{1}$, Shubham Nimbalkar ${ }^{1}$, Shubham Bawangade ${ }^{1}$, Sameer Ukey ${ }^{1}$, Poonam Lokhande ${ }^{1}$, \\ Piyush Bahad ${ }^{1}$, P. S. Patil ${ }^{2},{ }^{1}$ Jhulelal Institute of Technology, Nagpur, ${ }^{2}$ YCCE, Nagpur \\ Corresponding author Email: \{akshatagaurkhede003@gmail.com\}
}

\begin{abstract}
Among the various non-convectional energy resources, solar energy has great potential when it comes to conversion into electrical power. Increases efficiency of solar system is desirable for maximum power output. In order to maximise power output, needs to keep the panels in proper angle with the sun. This paper deal with the generation using solar power by window blinds. The proposed system ensures the optimization of the conversion of solar energy into electricity by properly orienting the panel in accordance with the position of the sun south facing window.
\end{abstract}

Keywords: Solar window blinds, Poly crystalline panel, inverter.

\section{Introduction}

Now days the solar energy is produced by the sunlight is a non-vanishing renewable source of energy which is free from eco-friendly. The solar energy is the most effective and non ending source of renewable source of energy. The solar energy reaches to earth in an hour from sun is sufficient for the energy demand of earth for whole year. Nowadays, solar energy is most important aspect of social-economic development. Solar windows where created for several applications. While everyone is enjoys having the energy savings and environmental benefits that traditional solar PV systems produce, not everyone likes the fight of large solar energy system on a roof or a property.

This window - based solar panels, which converts incident solar energy into electrical energy, without using any fossil fuel based energy production unit also it does not changes any look of the building or land. Solar power windows can also supplement clean electricity produce by convectional PV system. This solar system work based on the buildings which are south faced. This system is best for building with plenty of day time sun exposure. Window based solar technology is a revolutionary breakthrough for home owner and building owner we want to maximize efficiency and wouldn't otherwise be able to get enough energy for a PV solar system. PV cells is utilised to convert sun light into Direct Current (DC) electricity. The role of Charge controller is to control the power from solar panel and avoid power reverse to solar panel so that to prevent it from damage. Battery system is used as energy storage unit for electric power when sun light is not available (i.e. night). The system is connected to inverter for converting Direct Current (DC) into Alternating Current (AC).

\section{Need of Solar Power System}

The need of new technologies for the production of electrical energy is essential because of the increase in

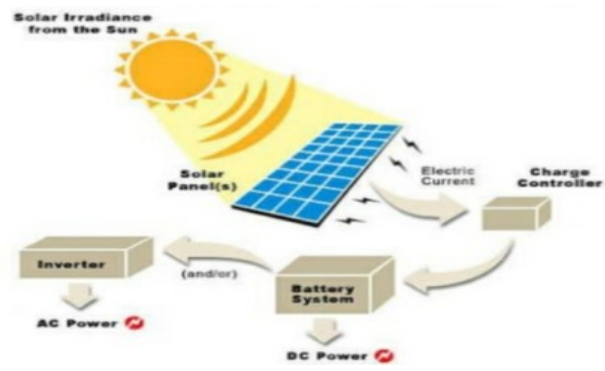

Fig.1.Working of Solar Energy

demand of energy, continuous reduction in existing fossil fuel and growing concern regarding environmental pollution. Most important aspect of the production of energy from renewable sources like solar energy is that it is a clean and pollution free method. Solar energy available is free in cost, practically inexhaustible and involves no polluting by- product or green gasses emissions.

\section{Objective}

Working with solar window blinds should be of following basic objectives:

a) Less space required: Now days, most of the people install solar panel on their roof top and they get more Space. So, instead of this we are installing solar panel on windows and getting less space.

b) Generation of electricity: With the help of waste heat which falls on window we are generating electricity by using solar panel.

c) Green technology: Solar power is pollution free and causes no greenhouse gasses to be emitted after installation. It will not create noise and wear and tear will be minimized.

It does not required fuel to generate electricity so it does not produce waste and therefore, there will be no pollution issue.

d) Energy bill reduce: The use of solar panel instead of depending on a utility company can help you cut your bill by up to $50 \%$ per month. When your home has solar panel, energy from the sun will be 
use to power your electricity. Except for when the sun is not present such as during thunder storm is at night.

\section{Methodology \& System Development}

Solar system with window is as shown in the above fig. it is placed in south facing side. Sun rays are incident on the solar panel. Solar panel traps the light energy and converts into electricity. We are use in Poly crystalline modules which are the convert heat energy into electric energy. Poly crystalline module works on the basic principle by absorbing sun light with photovoltaic cell, generating DC energy and then converting it to useable alternating current. Solar panel mounted on window which gets heated and the poly crystalline module converts heat into electricity.

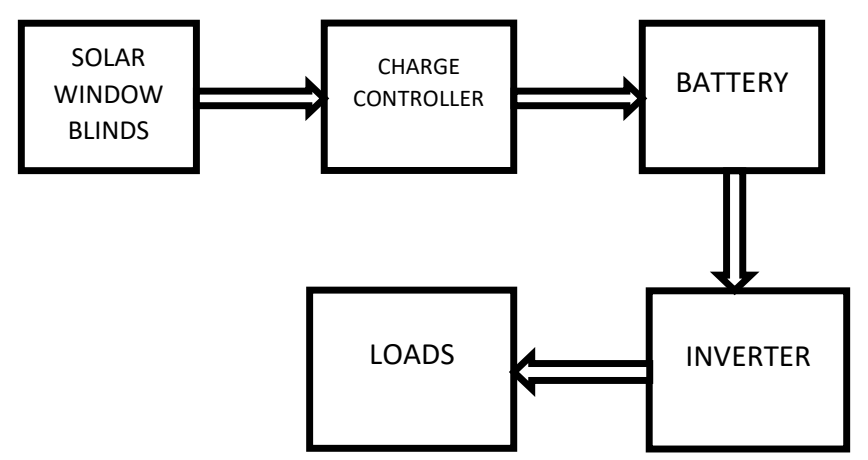

Fig.2 Block Diagram

The solar panel mounted on the window having positive and negative which are connected to the charge controller and the charge controller is connected to the battery as well as load. And battery is connected to the inverter with step-up transformer. Four solar panel module are placed on the window. When there is a sufficient heat available on the panel the module generates electric energy. When temperature is more output is maximum. As temperature varies output of the panel also varies. This methodology applied in the form of working module at window having size of 2 feet* 4 feet. Aluminium framed window having weight about $3 \mathrm{Kg}$.

\section{$>$ Solar Panel Specifications:}

1. Size: $290 \times 640 \times 25 \mathrm{~mm}$

2. Voltage Rating: 12 Volt

3. Wattage Rating: 35Watt

4. Weight 500 gm each panel

5. Red wire indicates in positive

6. Black wire indicates in negative

Like above whole system consist of Battery, Inverter, Charge Controller \& Transformer circuits with panels. The solar panel which is mounted on the window are connected in parallel. The power from the solar panel is given to charge controller (21Volt, 0.8Amp). From the ISSN (Print): 2456-6411 | ISSN (Online): 2456-6403 charge controller the power is delivered to battery. Once the charge controller get power from solar panel its start their work and controlled voltage to $12 \mathrm{Volt}$ and fed to the battery. The battery also supplies DC to the inverter. Inverter having step-up transformer (12Volt to 230Volt). The inverter is based on MOSFET inverter.

The IRFZ44n is a N-channel MOSFET. We are using two MOSFET attached to the heat sink. One MOSFET is connected to the transformer input to one wire and second MOSFET is also connected to the transformer with another wire. When the MOSFET start conducting after this DC power which comes from battery covert into $\mathrm{AC}$ power. By the input of the transformer we get 12 Volt voltage and step-up to 230 Volt and by the output of transformer we get $230 \mathrm{Volt}$ and fed to the main switch and ready to give supply give load.

\section{Result Analysis}

Output of methodology is analyzed with different case studies with loads.

Battery charging time: from $7 \mathrm{AM}$ to $12 \mathrm{PM}$ it get $50 \%$ charging. from $12 \mathrm{PM}$ to $5 \mathrm{PM}$ it get $95 \%$ charging. The charging of battery its depend on intensity sun rays. Output of the system is about 140 watt for which various cases are studied.

Case Study: 1

\begin{tabular}{|c|c|c|c|c|c|}
\hline $\begin{array}{c}\text { Sr. } \\
\text { No. }\end{array}$ & Load & $\begin{array}{c}\text { No. of } \\
\text { Loads }\end{array}$ & Ratings & $\begin{array}{c}\text { Total } \\
\text { output }\end{array}$ & $\begin{array}{c}\text { Used } \\
\text { power }\end{array}$ \\
\hline 1 & Fan & 1 & $70 \mathrm{w}$ & & $70 \mathrm{w}$ \\
\hline 2 & Light & 2 & $40 \mathrm{w}$ & & $40 \mathrm{w}$ \\
\hline Total & & 3 & & $140 \mathrm{w}$ & $110 \mathrm{w}$ \\
\hline
\end{tabular}

From this study we conclude that when we used the 110w load it runs 3 to 4 hours, this is a discharge time of battery for this case.

\section{Case Study:2}

\begin{tabular}{|c|c|c|c|c|c|}
\hline $\begin{array}{c}\text { Sr. } \\
\text { No. }\end{array}$ & Load & $\begin{array}{c}\text { No. } \\
\text { of } \\
\text { Load }\end{array}$ & Rating & $\begin{array}{c}\text { Total } \\
\text { output }\end{array}$ & $\begin{array}{c}\text { Used } \\
\text { power }\end{array}$ \\
\hline 1 & Fan & 1 & $70 \mathrm{w}$ & & $70 \mathrm{w}$ \\
\hline 2 & Light & 1 & $20 \mathrm{w}$ & & $20 \mathrm{w}$ \\
\hline 3 & $\begin{array}{c}\text { Mobile } \\
\text { charger }\end{array}$ & 1 & $6 \mathrm{w}$ & & $6 \mathrm{w}$ \\
\hline Total & & 3 & & $140 \mathrm{w}$ & $96 \mathrm{w}$ \\
\hline
\end{tabular}

From this study we conclude that when we used the 96w load it runs 4 to 5 hours, this is a discharge time of battery for this case.

\section{Conclusion:}

The paper has presented a preliminary study on the solar window blind by various cases with the loads. Literatures provided beneficial data for proposed 
methodology. The concept of solar window blinds is advantageous for the generation of electricity for reducing your energy bill and save your space. Installation costs for this system is also low. It will be more effective when installed for large no windows. This methodology can be used for corporate buildings, residential appartment, offices, collages, etc.

\section{Reference:}

[1] B. Cazes, "windows and glazed area technologies and materials in Europe", presented at the IEA (International Energy Agency) Building Envelope Technologies and Policies Workshop, Neuilly-surSeine, France, 17 November 2011

[2] X. Long, R. Lion and J. Zhoul "Low cost charge controller of photovoltaic power conditioning system based dynamic DC/DC topology" IET Renew. Power Generation., 2011, vol. 5,Iss. 2, pp. 167-174.
[3] Kjaer, S.B.; Pedersen, J.K;Blaabjerg, F.; “A review of single-phase grid connected inverters for photovoltaic modules", IEEE Transactions on Industry Applications, Volume 41, Issue 5, pp. 1292 - 1306, Sept.-Oct. 2005

[4] AkshayUrja (2008) special issue on Solar Energy for Urban and IndustrialAapplications. Vol. 1. NO. 5. March-April 2008. Ministry of New and Renewable Energy, Government of India.

[5] B. P. Divakar and Danny Sutanto "Optimum Buck Converter with a Single Switch" IEEE Power Electronics, July 1999. Vol. 14, No.4. 